\title{
Measuring Customer Satisfaction in the Parcel Service Delivery: A Pilot Study in Malaysia
}

\author{
Hoo Lien Yee \\ School of Management, Faculty of Management and Information Technology \\ UCSI University, Malaysia \\ Jalan Menara Gading, UCSI Heights, 56000 Kuala Lumpur, Malaysia \\ Dazmin Daud \\ School of Management, Faculty of Management and Information Technology \\ UCSI University, Malaysia \\ E-mail: dazmindaud@ucsi.edu.my
}

Received: November 10, 2011 Accepted: November 24, 2011 doi:10.5296/ber.v1i1.1125

\begin{abstract}
The purpose of this paper is to examine the level of customer satisfaction in the parcel service delivery. A questionnaire survey based on the SERVQUAL model was carried out among 103 parcel service delivery users from the Cheras area, Kuala Lumpur. It was found that tangibility, reliability and assurance each has an impact on customer satisfaction; while empathy and responsiveness have no significant impact on customer satisfaction. The paper contributes to our knowledge on customer satisfaction by presenting the service qualities from a customer perspective and by deriving an effective approach to focus on the important dimensions in the SERVQUAL model in the parcel service delivery business. Implications and limitations from this study are also discussed.
\end{abstract}

Keywords: SERVQUAL model, Service, Parcel service delivery (PSD), Customer satisfaction 


\section{Introduction}

\subsection{Background of the Problem}

The theme pertaining to parcel service delivery (PSD) is that it consists of carriers that transport shipments which typically small to be handled by one person (Morlok, Nitzberg, Balasubramaniam \& Sand, 2000). In logistics, the PSD is part of third-party (3PL) service provider that ensures a smooth movement of goods within the supply chain (Vijayvargiva \& Dev, 2010). The 3PL therefore, acts as an external supplier that performs all or part of logistics activities for a company (Coyle, Bardi \& Langley, 2003). In the case of PSD, it is categorized under the standard 3PL provider (Hertz \& Alfredsson, 2003).

Vijayvargia and Dey (2010) argued that the selection of the 3PL service providers would depend on service qualities provided by these service providers. Meanwhile, Bourlakis and Melewar (2011) have highlighted factors that influence customers to select their 3PL service providers. These include the operational flexibility, the ability of the 3PL service provider to cope with a vast range of physical activities, ability to maximize level of service, geographical coverage provided, and product or market specialization.

According to Cronin and Taylor (1992), improving service quality is a must for PSD providers in order to attain competitive advantage. Failure to improve service quality in the parcel delivery services would lead to competitive disadvantages for these PSD providers (Fabien, 2005) Therefore, an approach towards effective service quality is a measure for any services industries in order to gain customer satisfaction (Parasuraman, Zeithaml \& Berry, 1985) including the PSD providers. The model to measure customer satisfaction towards service quality is called the SERVQUAL model (Parasuraman et al., 1985). In supporting the model, Lovelock and Wirtz (2004) emphasized that the need to measure service quality is to compensate customer's money, time and effort by using services provided by a company. In other words, PSD providers must have a customer oriented in order to satisfy customers.

\subsection{Problem Statement and Research Question}

The objective of this study is to establish an empirical investigation of contributing factors that influence the customers' perception in selecting PSD providers. Despite the growing interest in PSD providers and customer services, little empirical research has been conducted on the PSD in Malaysia (Noore Alam, 2008). This paper works toward indicating that the model of service quality from Parasuraman et al. (1985) leads to an understanding of customer's satisfactions and selecting PSD providers in Malaysia.

A research question was developed for this study:

What are the factors of SERVQUAL model that influence the customer satisfaction in selecting PSD providers?

This paper begins with a review of the literature on the dimensions of SERVQUAL model in relations to PSD, and PSD's customer satisfaction. Next, the research methodology, hypothesis testing and statistical findings are presented. Based on these, practical implications, limitations and conclusion are discussed. 


\section{Literature Review}

In the service quality theory, clients will determine the quality levels of services based on their expectation towards a firm (Oliver, 1980) Hence, customers' expectations serve as the foundation on which service quality is provided. Oliver further explained that as service quality increases, satisfaction from the customer increases.

In relation to PSD, an empirical study by Park and Regan (2004) examined the impact of e-commerce on home delivery operations. Their study indicated that the logistical requirements of e-commerce goods may stimulate greater complexity in supply chain management and potentially cause higher costs in carrier fleet operations. In the $21^{\text {st }}$ century, PSD providers are expected to continuously and quickly change its organization, process, people, products, facilities, information systems, performance measures, and business partners to adapt in to a continuously changing business environment (Bititci, Martinez, Albores \& Mendible, 2003).

A concept called a "collaborative agile enterprise" emerges when PSD providers keen to stay competitive in the business (Bititci et al., 2003). For instance, the parcel delivery United Parcel Service (UPS)'s has created a unit called the Service Parts Logistics (SPL) (Laurie, Doz \& Sheer, 2006). Through SPL, UPS has institutionalized the capabilities and skills for identifying and developing opportunities for competitive advantage.

Parasuraman et al. (1985) have developed a service quality model known as SERVQUAL. The model provides as an instrument for measuring service quality. There are five dimensions in the model namely tangibility, reliability, assurance, empathy and responsiveness. In a related literature, Parasuraman, Berry and Zeithaml (1991) emphasized that the dimension of reliability refers to the core aspects of the service while the other dimensions refer to the relational or process of the service provided.

Banomyong and Supatn (2011) described three areas of tangible dimension: assets, personnel and availability. Assets are referred to physical instruments and operative means (outlets location and web sites) while personnel are referred to employees who generate products and contribute to the control of logistics activities. Availability is referred to any instruments that indicated the existence of products along the transportation process.

Kersten and Koch (2010) explained the importance of reliability dimension based on promising time delivery, solving customer problems, doing right at the first time, delivering on time, and delivering damage-free goods. This dimension, therefore, describes the relationship between service and time.

Meanwhile, the dimension of assurance contains factors of credibility, security, competency and courtesy as the measurement scales (Parasuraman et al., 1991). In the PSD, the scope of this dimension is to assess knowledge and courtesy of employees and their ability to inspire trust and confidence towards customers (Jun, Yang \& Kim, 2004). This also can relate to the responsiveness dimension where it focuses on quick response and ability to get help if the customers have a problem or question (Parasuraman et al., 1985). 


\section{Macrothink

The last dimension for service quality in the SERVQUAL is empathy. It refers to the individual service given by the PSD to its customers (Vega \& Garcia, 2008). Vega and Garcia argue that customers are concerned on issues pertaining to giving individual attention, conveniences of operating hour, personal attention and understanding special needs when they choose their PSD service provider.

The success or the failure of service providers depends on how these service providers understand customer satisfaction based on their service performance (Banomyong \& Supatn, 2011). In theory, customers' satisfaction is the forward-looking metric because it will affect the market share erosion to fall when it starts slipping (Kotler, 2003). Customer loyalty exists when these firms demonstrate reliability in their services toward customers (Coltman et al., 2008; Parasuraman et al., 1991).

In the of the SERVQUAL model, it also should be stressed weaknesses of the model. Buttle (1996) explains that SERVQUAL's 5 dimensions are not universals, and that the model fails to draw on established economic, statistical and psychological theory. Despite these weaknesses, the model remains a useful instrument for service-quality research for the past 20 years (Ladhari, 2009).

\section{Research Framework}

This paper focuses on how the dimensions of service quality (tangibility, reliability, assurance, responsiveness and empathy) affect the customers' satisfaction in using PSD providers. By examining the relationship between the five dimensions in the SERVQUAL model and customer satisfaction should contribute to extend knowledge of the relationship that exists between them. The link between the dimensions of service quality and customer satisfaction is illustrated in Figure 1.0. In this theoretical framework, service quality dimensions are independent variables and customer satisfaction is a dependent variable. The framework suggests services from PSD providers are associated with customer satisfaction.

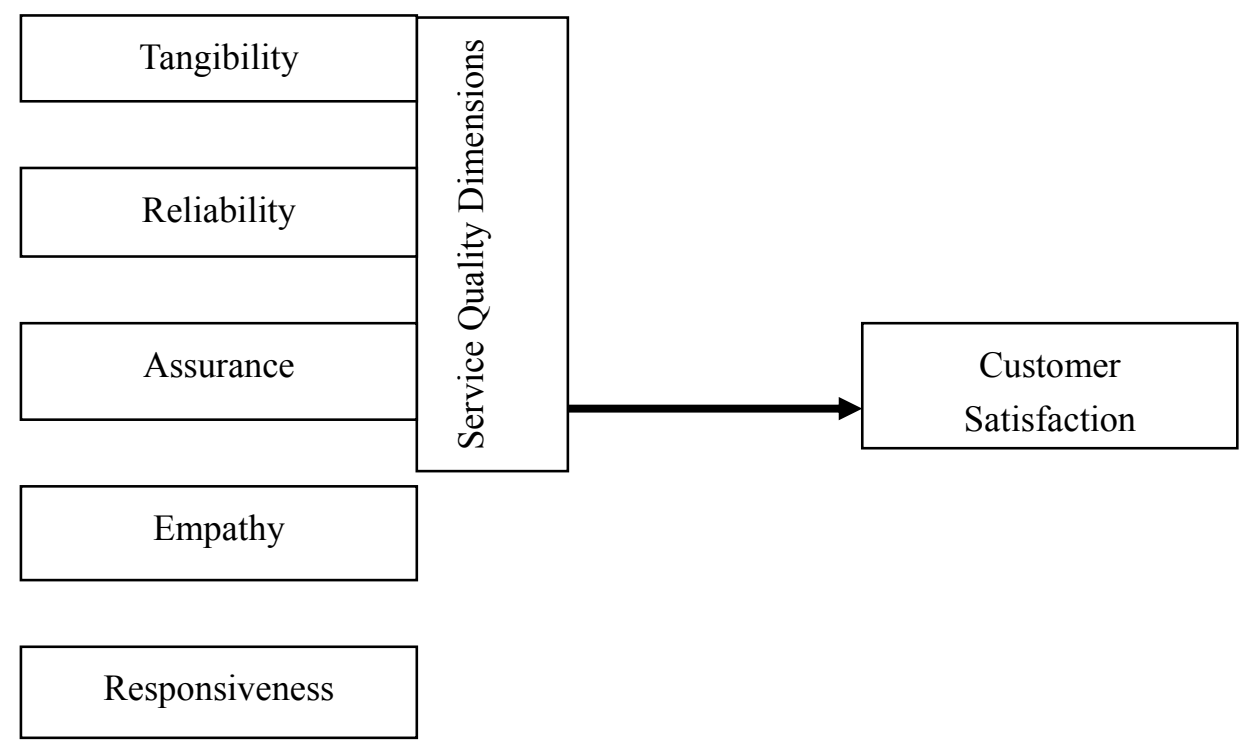

Figure 1. The Research Framework 
The following hypotheses are proposed:

H1: PSD providers' tangibility is associated with customer satisfaction.

H2: PSD providers' reliability is associated with customer satisfaction.

H3: PSD providers' assurance is associated with customer satisfaction.

H4: PSD providers' empathy is associated with customer satisfaction.

H5: PSD providers' responsiveness is associated with customer satisfaction

\section{Methodology}

In this section we discuss sample and data collection procedures in the study as well as the statistical tests applied to test the hypothesis.

\subsection{Sampling Procedure}

The target population of this study is people who have experience in using the PSD. The survey was conducted between May and June 2011. As this is a pilot study, a non-probability sampling was used. Out of the 110 self-administered questionnaires distributed to the public within the Cheras area in Kuala Lumpur, 103 usable questionnaires were returned, yielding a response rate of 93.6 percent.

There were 67 ( 65 percent) male and 36 (35 percent) female respondents. Out of this group of respondents, the majority of them were aged between $20-30$ years old ( 88.3 percent). 53 (51.5 percent) of respondents used PSD on yearly basis. The remaining 33 (32 percent), 12 (11.7 percent) and 5 (4.9 percent) of the respondents used PSD on monthly, weekly and daily basis respectively.

\subsection{Variable Measurements}

\subsubsection{Independent Variables: Service Quality Dimensions}

This measure was based on 22 items which attribute to the five dimensions of the SERVQUAL model developed by Parasuraman et al. $(1985 ; 1991)$ with appropriate changes to make the items more relevant to the present study. Responses to these items were made on a five-point Likert format which ranged from 1 = "strongly disagree" to 7 = "strongly agree".

\subsubsection{Dependent Variable: Customer Satisfaction}

Zeithaml, Berry and Parasuraman (1993) define customer satisfaction as a gap between expected service and perceived service provided by a firm towards its customer. This was operationalised by a three-item scale from the SERVQUAL model. Each item requires the respondents to indicate their perceptions on a seven-point Likert format from 1 = "strongly disagree" to 7 = "strongly agree".

\subsection{Analysis of Data}

The Statistical Package for Social Science (SPSS) Version 17 was used for the questionnaire data analysis. Demographical characteristics captured through questions with respect to 
gender, age group and experience of using PSD.

\section{Results of the Survey}

\subsection{Reliability Analysis}

The reliability of the questionnaire was tested according to Cronbach's Alpha measurements (Table 1.0). The reliability of each dimension of service quality and customer satisfaction was as follows: tangibility ( 81 percent); reliability ( 86 percent); assurance ( 86 percent); empathy ( 85 percent); responsiveness ( 83 percent) and customer satisfaction ( 80 percent). Thus, all the reliability values are adequately meeting the standards for further research (Nunnally, 1967). Table 1.0 also indicates the values of means and standard deviations for all the variables.

Table 1. Reliability of Service Quality Dimensions and Service Satisfaction ( $\mathrm{n}=103)$

\begin{tabular}{|l|l|l|l|l|}
\hline Variable & Number of Items & Cronbach's Alpha & Mean & SD \\
\hline Tangibility & 4 & .81 & 4.93 & 0.92 \\
\hline Reliability & 5 & .86 & 5.48 & 1.04 \\
\hline Assurance & 4 & .86 & 5.21 & 1.03 \\
\hline Empathy & 5 & .85 & 4.99 & 1.04 \\
\hline Responsiveness & 4 & .83 & 5.07 & 1.06 \\
\hline Customer Satisfaction & 3 & .80 & 5.38 & 0.98 \\
\hline
\end{tabular}

In relations to means and standard deviations, Table 1.0 indicates that respondents perceived reliability $(\mathrm{M}=5.48, \mathrm{SD}=1.04)$ to be the most dominant variable, followed by customer satisfaction $(\mathrm{M}=5.38, \mathrm{SD}=0.98)$, assurance $(\mathrm{M}=5.21, \mathrm{SD}=1.03)$, responsiveness $(\mathrm{M}=$ $5.07, \mathrm{SD}=1.06)$, tangibility $(\mathrm{M}=4.93, \mathrm{SD}=0.92)$ and empathy $(\mathrm{M}=4.99, \mathrm{SD}=1.04)$ which were all rated as "somewhat agree".

\subsection{Simple Regression Analysis}

A simple regression analysis was conducted to examine the relative impact of service quality dimensions on customer satisfaction. As indicated in Table 2.0, the SERVQUAL model dimensions were significantly accounted for .73 (i.e. R Square) of the variance in dependent variable (customer satisfaction). The F statistics yielded for 52.56 in customer satisfaction at the 95 percent confidence level. The results of regression analysis supported hypotheses $\mathrm{H} 1$, $\mathrm{H} 2$ and $\mathrm{H} 3$ but not hypotheses $\mathrm{H} 4$ and $\mathrm{H} 5$. $\mathrm{HI}, \mathrm{H} 2$ and $\mathrm{H} 3$ posited a positive causal relationship $(\mathrm{H} 1: \beta=.14, \mathrm{t}=2.01 \mathrm{p}=.047 ; \mathrm{H} 2: \beta=.28, \mathrm{t}=3.98, \mathrm{p}<.001 ; \mathrm{H} 3: \beta=.45, \mathrm{t}=$ $4.99, \mathrm{p}<.001)$. 
Table 2. Results of Regression Analysis of the Service Quality Dimensions and Customer Satisfaction

\begin{tabular}{|l|l|l|l|l|l|}
\hline & Sum of Squares & df & Mean Square & F & Sig. \\
\hline Regression & 152.86 & 5 & 30.57 & 52.56 & $.000^{*}$ \\
\hline Residual & 56.42 & 97 & .58 & & \\
\hline Total & 209.28 & 102 & & & \\
\hline R Square $=.73$; Adjusted R Square $=.72$ & \multicolumn{5}{l|}{} \\
\hline Independent Variables & Standardized Coefficients & $\mathrm{t}$ & \multicolumn{2}{l|}{} \\
\hline Tangibility & .14 & 2.01 & Sig. \\
\hline Reliability & .28 & 3.98 & $.047^{*}$ \\
\hline Assurance & .45 & 4.99 & $.000^{*}$ \\
\hline Empathy & .10 & 1.39 & $.000^{*}$ \\
\hline Responsiveness & .05 & 0.56 & .169 \\
\hline
\end{tabular}

* significance at $\mathrm{p}=.05$ level (2-tailed)

\section{Discussion}

The results of this study revealed that tangibility, reliability and assurance from the SERVQUAL model were significant to customers' satisfaction. In relation to tangibility dimension, studies from Nor Khalidah (2004) and Keillor, Hult and Kandemir (2004) indicated that factors such as appearance of personnel, physical facilities, modern looking equipment and materials associated with service are visually appealing are the important to services providers for ensuring customer satisfaction.

As for the reliability dimension, the results indicated that customers are satisfy when the PSD providers are able to ship items within promised time, show interest in solving problems, parcel carriers get thing right at first time and parcel carriers provide service within time they promise, they would gain customer loyalty and satisfaction (Notteboom \& Rodrigue, 2008). In addition to that, an order fulfillment can be measured for customer satisfaction when the order time and when the items received by customers are within the acceptable cycle time (Rushton, Croucher \& Baker, 2006).

Employees' performance plays an important role in determining customer satisfaction by demonstrating assurance (Parasuraman et al., 1991). This statement is supported by Jun et al. (2004) which explained that employees who perform their job based on knowledge and courtesy would contribute customers' confidence. In the PSD industry, the behaviour of personnel in parcel carrier, feel safe dealing with carriers, ability of personnel to answer your questions and courteous performance made by personnel would attribute to assurance dimension (Han, Chou \& Liang, 2003).

In this study, empathy and responsiveness dimensions indicated non-significant results. The findings are contrast with the previous studies where empathy and responsiveness did indicate significant impact on customer satisfaction in logistics services (for examples Mentzer, Flint \& Holt, 2001; Stank, Goldsby, Vickery \& Savitskie, 2003). Further study should be performed in order to examine these non-significant results for empathy and 
responsiveness dimensions.

\section{Limitations and Future Research}

There are some limitations that must be considered in future research. Firstly, a major limitation of this study is the small sample size $(n=103)$. Therefore, the power of the test is weaker. When a study has a lower sample size, the likelihood of encountering Type-I and Type-II errors occurring is higher (Schultz \& Grimes, 2005). If the study has a higher sample size, it allows increasing the significance level of the findings. Large sample size is expected to represent the characteristics of the population studied. As this study is only a pilot, further research with appropriate sample size and sampling technique should be performed in future.

Finally, data were collected at the single point in time, which does not allow for changes in perceptions over time. It is suggested a longitudinal study needs to be conducted for future research.

\section{Conclusion}

In conclusion, this study reports on exploratory investigation of the relationship between dimensions in the SERVQUAL model and customer satisfaction in PSD industry. This study endeavours to make both theoretical and practical contribution to the literature, and it also provides several implications for future research.

The findings enhance our understanding of the customer satisfaction in using PSD. This study has also provided us with better understanding of the dominant dimensions in the SERVQUAL model that influence customer satisfaction in PSD industry.

\section{References}

Bititci, U.S., Martinez, V., Albores, P. \& Mendible, K. (2003). Creating and sustaining competitive advantage in collaborative systems: The what? And the how? Production Planning \& Control, 14(5), 410-424. http://dx.doi.org/10.1080/0953728032000112331

Bonomyong, R. \& Supatn, N. (2011). Selecting logistics providers in Thailand: a shippers' perspective. European Journal of Marketing, 45(3), 419 - 437.

Bourlakis, M. \& Melewar, T.C. (2011). Marketing perspectives of logistics service providers: Present and future research directions. European Journal of Marketing, 45(3), 300 - 310.

Buttle, F. (1996). SERVQUAL: Review, critique, research agenda. European Journal of Marketing, 30(1), 8 - 32. http://dx.doi.org/10.1108/03090569610105762

Coltman, T., Keating, B., Anderson, E., Devinney, T. \& Gattorna, J. (2008). What do 3PL customers really want? Australian Freight Logistics, 10, February/March 2008, 22 - 23.

Coyle, J., Bardi, E. \& Langley, J. (2003). The Management of Business Logistics: A Supply Chain Perspective. Cincinnati, OH: South-Western College Publication.

Cronin, J. \& Taylor, S. (1992). Measuring service quality: a reexamination and extension, Journal of Marketing, 56(3), 55-68. http://dx.doi.org/10.2307/1252296 
Fabien, L. (2005). Design and implementation of a service guarantee. Journal of Services Marketing, 19(1), 33-38. http://dx.doi.org/10.1108/08876040510579370

Han, T., Chou, T. \& Liang, G. (2003). A demand analysis of cargo terminal in Taiwan's international airport. Journal of the Eastern Asia Society for Transportation Studies, 5, 526 -541 .

Hertz, S. \& Alfredsson, M. (2003). Strategic development of third party logistics providers. $\begin{array}{llllll}\text { Industrial } \quad \text { Marketing } \quad \text { Management, } & 32(2), & 139 & - & 149 .\end{array}$ http://dx.doi.org/10.1016/S0019-8501(02)00228-6

Jun, M., Yang, Z. \& Kim, D. (2004). Customers' perceptions of online retailing service quality and their satisfaction. International Journal of Quality \& Reliability Management, 21(8), 817-840. http://dx.doi.org/10.1108/02656710410551728

Keillor, B. D., Hult, G. T. M., \& Kandemir, D. (2004). A study of the service encounter in eight countries. Journal of International Marketing, 12(1), 9-35. http://dx.doi.org/10.1509/jimk.12.1.9.25649

Kersten, W. \& Koch, J. (2010). The effect of quality management on the service quality and business success of logistics service providers. International Journal of Quality \& Reliability Management, 27(2), 185 - 200. http://dx.doi.org/10.1108/02656711011014302

Kotler, P. (2003). Marketing Insights from A-Z: 80 Concepts Every Manager Needs to Know. Hoboken, NJ: John Wiley \& Sons. http://dx.doi.org/10.1108/17566690910971445

Ladhari, R. (2009). A review of twenty years of SERVQUAL research. International Journal of Quality and Service Sciences, 1(2), 172 - 198.

Laurie, D.L., Doz, Y.L. \& Sheer, C.P. (2006). Creating new growth platforms. Harvard Business Review, 84(5), 80-90.

Lovelock, C.H. \& Wirtz, J. (2004). Services Marketing: People, Technology, Strategy (5 ${ }^{\text {th }}$ ed.). Englewood Cliffs, NJ: Prentice Hall.

Mentzer, J.T., Flint, D.J. \& Holt, T.M. (2001). Logistics service quality as a segment-customized process. Journal of Marketing, 65(4), 82-104. http://dx.doi.org/10.1509/jmkg.65.4.82.18390

Morlok, E.K., Nitzberg, B.F., Balasubramaniam, K. \& Sand, M.L. (2000). The parcel service industry in the U.S.: Its size and role in commerce. School of Engineering and Applied Science, University of Pennsylvania, Philadelphia, PA. Retrieved November 26, 2011 from http://www.seas.upenn.edu/sys/logistics/parcelstudy.html.

Noore Alam, S. (2008). Service delivery innovations and governance: The Malaysia experience. Transforming Government: People, Process \& Policy, 2(3), 194-213.

Nor Khalidah, A. (2004). Service quality dimensions: A study on various sizes of grocery retailers -A conceptual paper. Proceeding of IBBC 2004, 633-642. 
Notteboom, T. \& Rodrigue, J. (2008). Containerisation, box logistics and global supply chains: The integration of ports and liner shipping networks. Maritime Economics \& Logistics, 10(1-2), 152 - 174. http://dx.doi.org/10.1057/palgrave.mel.9100196

Nunnally, J. (1967). Psychometric Theory, New York, NY: McGraw-Hill.

Oliver, R. (1980). A cognitive model of the antecedents and consequences of satisfaction decisions. Journal of Marketing, 17(10), 460 - 469.

Parasuraman, A., Berry, L.L. \& Zeithaml, V.A. (1991). Understanding customer expectation of service. Sloan Management Review, 32(3), 39 - 48.

Parasuraman, A., Zeithaml, V. A. \& Berry, L. L. (1985), A Conceptual Model of Service Quality and Its Implications for Future Research. Journal of Marketing, 49(4), 41 - 50. http://dx.doi.org/10.2307/1251430

Park, M. \& Regan, A. (2004). Issues in emerging home delivery operations. Research paper, University of California, Institute of Transportation Studies, Los Angeles, CA.

Rushton, A, Croucher, P. \& Baker, P. (2006). The Handbook of Logistics and Distribution Management. Philadelphia, PA: Kogan Page.

Schultz, K.F. \& Grimes, D.A. (2005). Sample size calculations in randomized trials: Mandatory and mystical. Lancet, 365(9467), $1348 \quad-\quad 1353$. http://dx.doi.org/10.1016/S0140-6736(05)61034-3

Stank, T.P., Goldsby, T.J., Vickery, S.K. \& Savitskie, K. (2003). Logistics service performance: Estimating its influence on market share. Journal of Business Logistics, 24(1), 27-55. http://dx.doi.org/10.1002/j.2158-1592.2003.tb00031.x

Vega, M.G. \& García, J. (2008). Measuring Customer Satisfaction in a Service Company combining approaches for Quality Service Improvement. Journal of Retailing and Consumer Services, 6, $270-275$.

Vijayvargiya. A, \& Dey, A.K. (2010). An analytical approach for selection of a logistics provider. Journal of Management History, 48(3), 403 - 418.

Zeithaml, V.A., Berry, L.L. \& Parasuraman, A. (1993). The nature and determinants of customer expectations of service. Journal of the Academy of Marketing Science, 21(1), 1 - 12. http://dx.doi.org/10.1177/0092070393211001

\section{Copyright Disclaimer}

Copyright reserved by the author(s).

This article is an open-access article distributed under the terms and conditions of the Creative Commons Attribution license (http://creativecommons.org/licenses/by/3.0/). 